\title{
The effect of addition of interstitial brachytherapy for improving the local control rate in advanced carcinoma of cervix
}

\author{
Dillip Kumar Parida, Subhash Chander, R.C.Joshi, Goura Kishore Rath
}

\begin{abstract}
Abstrak
Penelitian ini bertujuan untuk menilai peran bakhiterapi interstisial pada penanganan kanker serviks stadium lanjut. Tiga puluh enam pasien kanker serviks stadium III dan IV dengan bukti histopatologi dan telah mendapat terapi radiasi eksternal atau kombinasi kemoterapi - radiasi dimasukkan pada penelitian ini. Penelitian ini dilaksanakan antara Desember 1995 dan Juni 1999. Semua pasien tidak memenuhi syarat untuk brakhiterapi intrakaviter rutin. Indikasi klinik adalah geometri pelvik buruk (14), tumor residu (10), tumor residif (7) dan radiasi intrakaviter gagal (5). Total dosis radiasi yang diberikan adalah 28 - 32 Gy. Dengan median pengamatan lanjut adalah 15,5 bulan (kisaran 4 - 40 bulan), 21 (58,8\%) pasien menunjukkan bebas tumor lokal, 14 (38,8\%) dengan residu tumor dan 1 pasien mengalami tumor progresif. Pada kelompok kasus dengan tumor residu, efek paliatif terjadi pada 10 pasien. Kontrol lokal yang baik terjadi pada lesi tumor berdiameter $<4 \mathrm{~cm}$ dibanding dengan lesi bulky tumor. Komplikasi radiasi derajat I terjadi pada 8 pasien, derajat II terjadi pada 3 pasien dan tidak ada pasien yang mengalami komplikasi derajat III. Penanganan komplikasi derajat I dan II dilakukan secara konservatif. Tidak ada kematian akibat terapi ini. Tingkat ketahanan hidup pada 2 tahun dan 5 tahun adalah 34,7\% dan 10,6\% dengan median 21,8 bulan. Dapat disimpulkan bahwa transperineal template cukup aman diterapkan pada pasien kanker serviks yang tidak memenuhi syarat untuk brakhiterapi intrakaviter, karena distribusi dosisnya suboptimal untuk meningkatkan kontrol lokal.
\end{abstract}

\begin{abstract}
The study was undertaken with an aim to determine the role of interstitial brachytherapy in the management of advanced malignancy of uterine cervix. Thirty six histologically proven patients of cervical cancer of stage III and IV, previously treated with either external beam radiotherapy or combined chemo and radiotherapy were taken for the study between December 1995 and June 1999. All of the patients were not otherwise suitable for routine intracavitary brachytherapy. The clinical indications were poor pelvic geometry (14), residual disease (10), recurrent disease (7) and failed intracavitary radiotherapy (5). The total dose of radiation given was 28-32Gy. With a median follow up of 15.5 months (range 4-40 months), 21 (58.8\%) patients were having no evidence of disease locally, 14 $(38.8 \%)$ had residual disease and 1 patients was having progressive disease. In the residual disease group a better palliation effect was seen in 10 patients. The local control was better for the tumors $<4 \mathrm{~cm}$ in largest diameter compared to more bulky tumors. In 8 patients there was grade I, three patients had developed grade II complications and grade III complication was seen in no patients. Both grade I and II symptoms were managed conservatively. There were no acute treatment related deaths. The 2 and 5 years survival rate was $34.7 \%$ and $10.6 \%$ with a median of 21.8 months. Transperineal template can safely be practiced for the management of the patients of cervical cancer, not suitable for intracavitary brachytherapy or the dose distribution is sub-optimal by intracavitary procedure to improve local control rate.
\end{abstract}

Keywords: Transperineal template, interstitial brachytherapy, cervical cancer, radiotherapy

The cancer of uterine cervix is the second most common malignancy of the female genital tract worldwide. In Indian women it is the commonest form of cancer mortality and morbidity, accounting for $24 \%$ of all female malignancies. In all the cancer

Department of Radiation Oncology, All India Institute of Medical Sciences, New Delhi-110029 registries of India it tops the list of female malignancy except Mumbai and Delhi where breast cancer is the commonest. It is the only malignancy of female reproductive tract which can be prevented for its long pre-invasive clinical course by practice of an effective, inexpensive screening technique that allows the detection of pre-malignant conditions which can be treated effectively and not allowing them to develop into an invasive cancer. The possibility of clinical down staging as a result of screening and 
early detection should be considered. According to WHO report 1997 the most potential risk factors were identified and it was suggested that a decrease in the incidence of sexually transmitted disease in female population lower the chance of initiation of carcinoma cervix by $50 \%$. If the population between the age $35-$ 64 years are screened at an interval of 3 and 10 years, the incidence is decreased by 80 and $55 \%$ respectively. The incidence also falls by $30 \%$, when parity is less. ${ }^{1}$ There is an alarming incidence of about 524,000 new cases per year worldwide, out of which $80 \%$ occur in the developing countries. ${ }^{1}$ Unfortunately a great majority of the cases in India present at an advanced condition, when radiotherapy remains the mainstay of management. The usual institutional protocol of treating cancer cervix is to administer external beam radiotherapy (EBRT) from a tele-cobalt or linear accelerator by four field box technique followed by intracavitary radiotherapy (ICRT). But in certain challenging situations like patients having poor and inadequate pelvic geometry, recurrent or residual disease requiring re-irradiation and failed ICRT can be taken care by interstitial transperineal brachytherapy. In ideal situations a vaginal vault and cervical stump recurrence can be managed with interstitial brachytherapy. At our institution 40 patients with advanced carcinoma of cervix were managed with this technique.

\section{MATERIAL AND METHODS}

The facility of transperineal brachytherapy was started in December 1995 and thirty six patients of histopathologically proven patients of cancer cervix were taken for the procedure till January 1999. All the patients were assessed in the combined gynecological malignancy clinic before the procedure and properly explained regarding it with their consent. Routine haemogram, liver and renal function tests, X-ray of the chest was performed. Ultrasonogram (US) of the abdomen and pelvis alongwith transrectal US was done in order to asses the tumor extent and volume. CT scan of pelvis is done to see tumor infiltration. Pre-anesthesia checkup is mandatory before the procedure. The clinical indications were poor geometry (14), residual disease (10), recurrent disease (7) and failed ICRT (5). The patient is properly evaluated under anesthesia, uterine sounding was done to asses the length of the uterine cavity in order to finalize the length of the needle to be pushed in. The length of the vaginal canal is also measured and the first guide needle is put at $120^{\prime}$ clock position on the anterior lip of the cervix. The needles are of $18 \mathrm{G}$ size and having one end blind. The obturator is put in the vagina over the first guide needle and template positioning is done. The needles were put in a sequential manner starting from the inner circle. The template is secured by silk suture. In all the cases the procedure was performed using Syed-Neblett transperineal template. After the procedure is over, orthogonal X-ray pictures are taken in order to confirm the needles are in proper position, followed by treatment planning to get a homogeneous dose distribution inside the tumor volume and the Iridium192 sources were loaded. During the procedure care was taken not to perforate the rectal mucosa. The patients were followed up at an interval of six weeks for the first year, two monthly for the next year and three monthly for the third year. PAP smear and US is done every six months, CT scan of the abdomen and pelvis is done every year.

\section{RESULT}

The age range of the patients was between 36-65 years with a peak incidence between $50-60$ years. Out of the 36 patients, majority were having stage III (26) and rest were with stage IV disease. The most common presenting symptoms were pain over lower abdomen and back (36), vaginal discharge and bleeding (34), pain and swelling of the lower extremity (17) and pelvic mass in 7 patients. Majority of the patients were given general anesthesia (24), while (9) patients were managed with spinal and caudal anesthesia was administered to (3) patients during the procedure. Apprehensive patients were preferred to be treated with general anesthesia. The total dose of radiation administered was between 2832 Gy. The median treatment time was 48 hours( range 31-75 hours). Thirty patients were treated with EBRT to a total dose of 50Gy, 4 patients had received $66 \mathrm{~Gy}$ of EBRT alongwith 3 cycles of induction chemotherapy and two patients had radical radiotherapy to the pelvis by EBRT prior to transperineal interstitial brachytherapy procedure. The follow up period ranged from 4-40 months with a median of 15.5 months. At the time of analysis, 21 $(58.8 \%)$ patients were having no evidence of disease, $14(38.8 \%)$ had residual and 1 patients had progressive disease. Eight patients developed grade I and 3 had grade II urinary bladder complications and managed conservatively. The patients were declared to have no disease when the cervico-vaginal tumor bed is healed and clinically there is no tumor, pelvic 
tenderness comes down and the most important is PAP smear should revert back to normal.

\section{DISCUSSION}

The routine time tested gold standard protocol of treating an advanced cancer of uterine cervix with radiotherapy is delivering EBRT to the pelvis followed by intracavitary brachytherapy. Most of the patients fail locally than systemic. The prognosis is worse with advance stage, more bulky tumor, presence of lymph node and distant metastasis. The incidence of positive lymph node can also be attributed to the tumor diameter of more than $4 \mathrm{~cm}$ or more, lymphovascular invasion, deep invasion into cervical stroma and histologic grade of the tumor. ${ }^{2}$ All the above mentioned factors are responsible for a higher rate of recurrence. Perez and collegue have reported a total pelvic failure rate increases with the stage of the disease and accounted for stage I B $(10 \%)$, stage IIA (17\%), II B (23\%), III (42\%) and stage IV $(74 \%)$ after radiotherapy alone. ${ }^{3}$ The 10 year acturial incidence of distant metastasis is $39 \%$ and $75 \%$ in stage III and IV respectively. ${ }^{4}$ In order to achieve an optimal tumor control locally, a higher dose of radiation is required in advanced disease and bulky tumors. But in all reality it is not feasible because of the presence of many normal critical structures present around cervix and having a lower radiation threshold. Coia et al in a review of patterns of care study reported a survival rate of $65 \%$ at four years in the patients received a central tumor dose of $65 \mathrm{~Gy}$ compared to $42 \%$ in the patients with a lower dose $(\mathrm{p}<0.01)$. the local tumor control rate was $78 \%$ with a para-central dose more than 65 Gy versus $59 \%$ with a lesser dose $(p<0.01){ }^{5}$ Perez et al have reported a better rate of local control with a higher total dose to point A. More over the parametrium receiving a greater total dose was correlated with an improved tumor control. ${ }^{6}$ Keys and Gibbons have shown that the central disease requires a total dose of 80-90 Gy for maximal control probability, with larger tumors requiring further higher doses to the central necrotic region. $^{7}$ Because there is clinical limitations of delivering a higher total dose by EBRT alone and ICRT is unable to treat lateral pelvic wall optimally, interstitial brachytherapy have been used to supplement the routine external and intracavitary procedures with a comparable result with the standard treatment protocol. ${ }^{6}$ Nori et al have reported that the transperineal template is more desirable alternative to ICRT for its encouraging results in advanced cancer of cervix. ${ }^{8}$ Many literatures have shown interstitial brachytherapy to have an edge over routine procedures because of the feasibility of differential loading and unloading resulting in an intended higher total dose either to central or parametrial disease. ${ }^{9}$ The other advantages of a transperineal template are precise delivery of radiation to the predetermined treatment volume with a more homogeneous distribution which can be adapted to the irregular shape of the tumor with a considerable lesser dose to the sorrounding critical structures like urinary bladder, rectum and ureter. The principal benefit of the after loading procedure is to have the better control of distribution of radioactive sources and of the dose as well. Both of them can be adjusted within wide limits depending upon the clinical situation. In the present study most of the patients (21) were not suitable for the routine ICRT procedure and others were having residual or recurrent disease requiring reirradiation. It has been reported that the peak age incidence for carcinoma of cervix is between 48-55 years with a mean age of 53.8 and median of 51.5 years. ${ }^{10}$ In our patients the peak incidence was observed between 50-60 years of age (range36-65 years). Prempree et al have reported a local control rate of $96 \%$ and a five years disease free survival rate of $61 \%$ in the patients with stage IIIB disease, while the control group had a range between $25-48 \% .{ }^{11} \mathrm{~A}$ local control rate of $85 \%$ has been reported in the patients treated with interstitial brachytherapy. ${ }^{12,13}$ Demanes et al have reported an encouraging result of pelvic control to the tune of $95 \%$ in stage III and $75 \%$ in stage IV managing the patients with high dose rate transperineal interstitial brachytherapy. ${ }^{14}$ Puthawala et al have reported $50 \%$ of tumor control and $80 \%$ better palliation in the treatment group. ${ }^{15}$ In majority of our patients (34) the intensity of pain was decreased and there was no bleeding and discharge from vagina following the procedure. Nag et al have observed a local control rate of $51 \%$ in the patients having advanced disease and managed with interstitial brachytherapy. The local control rate was better for the tumors of size $4 \mathrm{~cm}$ or less in the largest diameter than the bulky ones. ${ }^{16}$ This aspect is also confirmed in our study. Such patients tolerated the treatment well and in 12/16 (tumor size $4 \mathrm{~cm}$ or less) patients there was complete regression of the tumor. Gupta et al have also reported that at 3 years the clinical complete response rate was $78 \%$. On univariate analysis for local control and disease volume were found to be statistcally significant. ${ }^{17}$ Twenty two $(55 \%)$ out of total 40 patients achieved local tumor control in our study group which is comparable with the literature. 
Many authors have reported the incidence of various grades of complications to the tune of $42 \%$ associated with the procedure. ${ }^{18}$ The complication associated with the procedure mostly dependant on the total treatment dose, dose rate of the radioactive isotope used, target volume and length of the treatment course. Inorder to achieve a low acceptable complication rate all the variables should be set optimally strictly according to the disease as well as patient and disease conditions. We treated 18 patients with a dose rate of $60 \mathrm{cGy}$ per hour, 13 patients with $50 \mathrm{cGy} / \mathrm{hr}$ and five patients with $40 \mathrm{cGy} / \mathrm{hr}$. Syed et al have reported that the incidence of bowel and bladder complication increases significantly with a dose rate of $80 \mathrm{cGy}$ or more per hour. ${ }^{19}$ Historically the placements of interstitial brachytherapy needles were put without visualization of the pelvic cavity. A major concern is direct injury to the pelvic viscera and small gut leading to complications. The use of diagnostic laparoscopy at the time of the procedure has been advocated to avert potential complications like perforation. ${ }^{20}$ Stock et al have also reported the use of transrectal ultrasonogram guided Syed-Neblett template implantation, that provides real time visualization of the target volume as well as normal tissues allowing accurate placement of the needles thus reducing the rate of associated complication. ${ }^{21}$ Nag et al have suggested the use of fluoroscopy to guide the needles in a parallel manner to obtain a better homogeneous dose distribution with less complication rate. ${ }^{22}$ In majority of our cases (29) there were no complications seen where as eight patients developed grade I and 3 had grade $I$ reactions.

\section{CONCLUSIONS}

Locally advanced or recurrent cervical cancer is highly responsive to radiation therapy and at least moderately curable with an effective and aggressive treatment modalities. Interstitial brachytherapy can precisely deliver a high dose of radiation to the tumor with low dose to the surrounding normal tissues and thus offers an alternative to ICRT for selected patients. When intracavitary dose distribution is expected suboptimal, this procedure is the only better option. Thus the addition of interstitial brachytherapy to EBRT improves the rate of local control rate in advanced carcinoma of uterine cervix.

\section{Acknowledgment}

Presented at the Young Scientist Award Session of VIII Biennial National Conference of the Indian
Society of Oncology, New Delhi 1999 and thanks to the Council of Scientific and Industrial Research (CSIR) for support.

\section{REFERENCES}

1. WHO report 1997

2. Chung CK, Nahlas WA, Stryker JA et al. Analysis of the factors contributing to treatment failures in stages IB and IIA carcinoma of the cervix. Am J Obstet Gynecol 1980;138:550-6

3. Perez CA, Grigsby PW, Camel HM et al. Irradiation alone or combined with surgery in stage IB, IIA and IIB carcinoma of uterine cervix: Update of a non-randomized comparison. . Int J Radiat Oncol Biol Phys 1995;31:703-16.

4. Fagundes H, Perez CA, Grigsby PW et al. Distant metastasis after irradiation alone in carcinoma of uterine cervix. Int J Radiat Oncol Biol Phys 1992;24:197-204.

5. Coia L, Won M, Lanciano $\mathrm{R}$ et al. The patterns of care outcome study for cancer of uterine cervix: Results of the Second National Practice Survey. Cancer 1990;66:2451-6.

6. Perez CA, Kuske R, Glasgow GP. Brachytherapy technique for gynecological tumors. Endocurie Hypertherm Oncol 1985;1:153-75.

7. Keys H, Gibbons SK. Optimal management of locally advanced cervical carcinoma. J Natl Cancer Inst Monogr 1996;21:89-92.

8. Nori D, Hilaris BS, Kim HS, Clark DG et al. Interstitial irradiation in recurrent gynecologic cancer. Int J Radiat Oncol Biol Phys 1981;7:1513-7.

9. Gaddis O, Morrow CP, Klement $\mathrm{V}$ et al. Treatment of cervical carcinoma employing a template for transperineal interstitial Ir-192 brachytherapy. Int J Radiat Oncol Biol Phys 1983;9:819-27.

10. Cramer D, Cutler SJ. Incidence and histopathology of malignancies of the female genital organs in the United States. Am J Obstet Gynecol 1974;118:443-60.

11. Prempree T. Parametrial implant in stage IIIB cancer of the cervix: A 5-year study. Cancer 1983;52:748-50.

12. Aristazabel SA, Surwit EA, Hevezi JM et al.Treatment of advanced cancer of the cervix with transperenial interstitial irradiation. Int $\mathbf{J}$ Radiat Oncol Biol Phys 1983;9:1013-7.

13. Martinez A, Edmundson GK, Cox RS et al. Combination of external beam irradiation and multiple site perineal applicator (MUPIT) treatment of locally advanced or recurrent prostatic, anorectal and gynecologic malignancies. Int J Radiat Oncol Biol Phys 1985;11:391-8.

14. Demanes DJ, Rodriguez RR, Bendre DD et al. High dose rate transperineal interstitial brachytherapy for cervical cancer: high pelvic control and low complication rates. Int J Radiat Oncol Biol Phys 1999;45(1):105-12.

15. Puthawala AA, Syed AM, Flemming PA et al. Reirradiation with interstitial implant for recurrent pelvic malignancy. Cancer 1982;50:2810-4.

16. Nag S, Martinez-Monge $\mathrm{R}$, Selman AE et al. Interstitial brachytherapy in the management of primary carcinoma of the cervix and vagina. Gynecol Oncol 1998;70(1):2732 . 
17. Gupta AK, Vicini FA, Frazier AJ et al. Iridium-192 transperineal interstitial brachytherapy for locally advanced or recurrent gynecological malignancies. Int J Radiat Oncol Biol Phys 1999;43(5):1055-60.

18. Ampuero F, Doss LL, Khan $M$ et al. The Syed-Neblett interstitial template in locally advanced gynecological malignancy. Int J Radiat Oncol Biol Phys1983;9:1897903.

19. Syed AMN, Puthawalla AA. Interstitial-intracavitary "Syed-Neblett" applicator in the treatment of carcinoma of the cervix. In Radiation therapy of gynecological cancer. $1^{\text {st }}$ ed 1987 Alan R Liss, Inc., New York.
20. Recio FO, Piver MS, Hempling RE et al. Laparoscopicassisted application of interstitial brachytherapy for locally advanced cervical carcinoma: Results of a pilot study. Int J Radiat Oncol Biol Phys 1998;40(2):41 1-4.

21. Stock RG, Chan K, Terk $M$ et al. A new technique for performing Syed-Neblett Template interstitial implants for gynecologic malignancies using transrectal-ultrasound guidance. Int J Radiat Oncol Biol Phys 1997;37(4):819-25.

22. Nag $S$, Martinez-Monge $R$, Ellis $R$ et al. The use of fluoroscopy to guide needle placement in interstitial gynecological brachytherapy. Int J Radiat Oncol Biol Phys 1998;40(2):415-20. 